\title{
PENGARUH MODEL PEMBELAJARAN INKUIRI TERBIMBING DENGAN METODE PEMBELAJARAN TERPADU KEMAMPUAN BERPIKIR KRITIS
}

\author{
Lu'luil Hayati $^{1}$, I Nyoman Loka ${ }^{2}$, Yunita Arian Sani Anwar ${ }^{3}$ \\ ${ }^{1,2,3}$ Program Studi Pendidikan Kimia FKIP Universitas Mataram \\ *Coressponding Author, Email: luluilhayati@gmail.com
}

Received: 19 September 2019

Accepted: 30 November 2019

Publish: 30 November 2019

doi: 10.29303/cep.v2i2.1364

\begin{abstract}
ABSTRAK
Penelitian ini bertujuan untuk mengetahui pengaruh model pembelajaran inkuiri terbimbing dengan metode pembelajaran terpadu terhadap kemampuan berpikir kritis. Jenis penelitian yang digunakan adalah quasi eksperiment dalam bentuk post-test only control group design. Populasi dalam penelitian ini meliputi seluruh siswa kelas XI MIA MAN 1 Lombok Timur sebanyak 154 siswa yang terdistribusi dalam 4 kelas. Metode yang digunakan untuk pengambilan sampel yaitu dengan metode purposive sampling. Sampel pada penelitian ini yaitu kelas XI MIA 4 sebagai kelas eksperimen dan kelas XI MIA 1 sebagai kelas kontrol. Pada kelas eksperimen diberi perlakuan dengan menggunakan model pembelajaran inkuiri terbimbing dengan metode pembelajaran terpadu sedangkan pada kelas kontrol diberi perlakuan dengan menggunakan model pembelajaran konvensional yaitu metode ceramah dan diskusi. Kemampuan berpikir kritis siswa difokuskan pada materi koloid dalam ranah kognitif. Uji hipotesis pada penelitian ini menggunakan uji Ancova (analysis of covariance). Hasil uji statistik pada taraf signifikan $5 \%$ menunjukkan fhitung $(8,15)>$ ftabel $(3,98)$. Nilai rata-rata kemampuan berpikir kritis kelas eksperimen sebesar 78,89 lebih tinggi dibandingkan kelas kontrol yaitu 73,24. Berdasarkan hasil uji statistik kedua kelas sampel menunjukkan bahwa penerapan model pembelajaran inkuiri terbimbing dengan metode pembelajaran terpadu memberikan pengaruh yang lebih baik terhadap kemampuan berpikir kritis siswa pada materi koloid siswa kelas XI MIA MAN 1 Lombok Timur.
\end{abstract}

Kata kunci : kemampuan berpikir kritis, materi koloid dan model pembelajaran inkuiri terbimbing dengan metode pembelajaran terpadu

\section{THE EFFECT OF GUIDED INQUIRY LEARNING MODEL WITH INTEGRATED LEARNING METHOD ON THE CRITTICAL THINKING SKILL}

\begin{abstract}
This research aimed to investigate the effecf of guided inquiry learning model with integrated learning method on the crittical thinking skill. This research used quasi experiment in the form of post-test only control group design. The population in research include all of XI grade student of MIA MAN 1 Lombok Timur were 154 students that distributed into 4 classes. Sampling method used in this research was purposive sampling metbod. The sample were XI grade MIA 4 as the experiment class and XI MIA 1 as control class. In experiment class was given treatment using guided inquiry learning with integrated learning method meanwhile on control class was given conventional learning method; lecture and discussion method. The crittical thinking skill was focussed on colloid in the cognitif scope. Hypothesis test used the Ancova test (analysis of covariance). The results of the statistical test at $5 \%$ significant level showed fcount (8.15) $>$ ftable (3.98). The average value of the
\end{abstract}


critical thinking skill of the experimental class was 78.89 higher than the control class which was 73.24. Based on the statistical test results of the two sample classes showed that the application of the guided inquiry learning model with integrated learning methods had a better effect on students' critical thinking skills in colloidal subject of 11th grade student of MIA MAN 1 East Lombok.

Keywords : critical thinking skills, colloidal and guided inquiry learning models with integrated learning method.

\section{PENDAHULUAN}

Kemampuan berpikir kritis merupakan cara berpikir relfektif dan berasalan yang difokuskan pada pengambilan keputusan untuk memecahkan masalah (Rahmadani \& Dian, 2018). Keterampilan berpikir kritis siswa seringkali kurang dapat berkembang dengan baik dalam proses belajar mengajar. Hal ini disebabkan pada umumnya pembelajaran di sekolah kurang mengarahkan siswa secara aktif dalam memperoleh pengetahuannya serta kurang melatih keterampilan berpikir kritis. Ada lima indikator berpikir kritis menurut Ennis (2011) yang diturunkan dari aktivitas kritis yakni: (1) merumuskan pokok-pokok permasalahan; (2) mengungkap fakta yang ada; (3) memilih argumen yang logis; (4) mendeteksi bias dengan sudut pandang yang berbeda; (5) menarik kesimpulan.

Penguasaan ilmu kimia ditunjukkan oleh hasil belajar siswa yang mencapai nilai kriteria ketuntasan minimal (KKM) yaitu 75 sebagai bukti bahwa siswa telah mencapai tujuan pembelajaran kimia. Namun yang terjadi ialah ilmu kimia dianggap sebagai pelajaran yang sangat sulit. Ilmu kimia yang abstrak menjadi semakin abstrak dan tidak dapat menarik minat siswa sehingga nilai kimia siswa masih cenderung di bawah KKM. Begitu pula yang terjadi di MAN 1 Lombok Timur, hasil belajar kimia siswa masih rendah karena nilai siswa yang cenderung di bawah KKM dilihat dari ketuntasan klasikal untuk semua kelas XI MIA masih di bawah $50 \%$.
Tabel 1. Nilai Rata-Rata Ulangan harian

\begin{tabular}{cccc}
\hline Kelas & $\begin{array}{c}\text { Jumlah } \\
\text { Siswa }\end{array}$ & $\begin{array}{c}\text { Nilai rata- } \\
\text { rata Ulangan } \\
\text { Harian } \\
\text { Kimia }\end{array}$ & $\begin{array}{c}\text { Ketuntasan } \\
\text { Klasikal }\end{array}$ \\
\hline $\begin{array}{c}\text { XI } \\
\text { MIA } 1\end{array}$ & 37 & 70,48 & $45,94 \%$ \\
\hline $\begin{array}{c}\text { XI } \\
\text { MIA 2 }\end{array}$ & 39 & 67,63 & $35,89 \%$ \\
\hline $\begin{array}{c}\text { XI } \\
\text { MIA 3 }\end{array}$ & 40 & 72,90 & $50 \%$ \\
\hline $\begin{array}{c}\text { XI } \\
\text { MIA 4 }\end{array}$ & 38 & 70,90 & $47,37 \%$ \\
\hline
\end{tabular}

(Sumber: Arsip Guru)

Rendahnya hasil belajar siswa tersebut dapat menjadi indikasi bahwa kemampuan berpikir kritis siswa kelas XI di MAN 1 Lombok Timur masih rendah. Hal ini sesuai dengan penelitian yang dilakukan oleh Surachman (2010) tentang hubungan antara keterampilan berpikir kritis dengan hasil belajar siswa memiliki nilai keterandalan $73,4 \%$. Penelitian yang dilakukan oleh Resti (2014) menunjukkan hasil yang sama dengan koefisien korelasi sebesar 0,954 yang artinya terdapat hubungan kuat antara keterampilan berpikir kritis dengan hasil belajar siswa.

Semua ini tidak terlepas dari bagaimana cara guru mengatur proses pembelajaran, baik dalam memilih atau menentukan model diikuti dengan penggunaan metode pembelajaran. Permasalahan tersebut terjadi karena dalam proses pembelajaran, guru lebih sering menggunakan model pembelajaran konvensional dengan metode ceramah dan diskusi yang tidak berbasis pembelajaran kooperatif pada proses pembelajaran kimia serta penggunaan metode yang tidak terpadu sehingga kelemahankelemahan dari masing-masing metode tidak bisa ditutupi oleh kelebihan metode lain. Guru juga membiasakan siswa menghafalkan 
beberapa konsep kimia, sehingga menurut guru siswa dapat menyelesaikan permasalahanpermasalahan dalam bentuk soal dengan baik. Partisipasi siswa dalam pembelajaran kimia juga rendah yang berarti masih banyak siswa yang belum aktif mengikuti pembelajaran di kelas (Aftriani, dkk., 2019).

Model pembelajaran inkuiri terbimbing dengan metode pembelajaran terpadu adalah model pembelajaran yang menekankan pengalaman-pengalaman belajar yang mendorong siswa dapat menemukan konsepkonsep dan prinsip serta pembelajaran yang melibatkan beberapa metode pembelajaran untuk memberikan pengalaman belajar yang bermakna bagi siswa. Pengaplikasian model inkuiri terbimbing memberi kesempatan kepada siswa untuk menemukan informasi dengan atau tanpa bantuan guru, menguji dan menafsirkan masalah secara sistematis sehingga diperoleh kesimpulan berdasarkan pembuktian (Usdalifat et al, 2016).

Penerapan model pembelajaran model pembelajaran inkuiri terbimbing dengan metode pembelajaran terpadu ini diharapkan siswa dapat memahami materi koloid karena siswa diajak untuk menghubungkan konsep yang ada kemudian membangun pengetahuannya sendiri bersama kelompok, diberikan kesempatan kepada siswa untuk merefleksikan apa yang telah ia dapat dan memperdalam pemahaman di akhir kegiatan pembelajaran sehingga diharapkan dapat meningkatkan kemampuan berpikir kritis siswa pada materi koloid.

Berdasarkan latar belakang yang telah diuraikan di atas, maka peneliti tertarik untuk melakukan penelitian dengan judul "Pengaruh Model Pembelajaran Inkuiri Terbimbing Dengan Metode Pembelajaran Terpadu Pada Materi Koloid Terhadap Kemampuan Berpikir Kritis Siswa Kelas XI MIA MAN 1 Lombok Timur".

\section{METODOLOGI PENELITIAN}

Penelitian ini dilakukan di MAN Lombok Timur pada tanggal 2 Mei sampai 16 Mei 2019. Penelitian ini termasuk kedalam jenis eksperimen semu (Quasi Experimental Design) yang terdiri dari kelas eksperimen dan kelas kontrol. Penelitian eksperimen semu digunakan karena pada penelitian ini sampel tidak dapat dikontrol sepenuhnya dari variabel-variabel luar yang mempengaruhi hasil belajar.

Desain penelitian yang digunakan dalam penelitian ini yaitu posttest only control group design. Sampel dalam penelitian ini yakni siswa kelas XI MIA 4 (38 siswa) sebagai kelas eksperimen dan XI MIPA 1 (37 siswa) sebagai kelas kontrol. Pengambilan sampel dilakukan dengan teknik purpossive sampling atau pengambilan sampel bertujuan (Sugiyono, 2014). Cara demikian dilakukan jika anggota populasi dipilih berdasarkan pertimbangan tertentu.

Penelitian ini dilakukan dengan pola pembelajaran pada kelas kontrol menggunakan model pembelajaran konvensional yaitu ceramah dan diskusi, sedangkan pada kelas eksperimen menggunakan model pembelajaran inkuiri terbimbing dengan metode pembelajaran terpadu Penerapan model dilakukan sebanyak 3 kali pertemuan selama 2 jam pelajaran $(2 \times 45$ menit). Pada pertemuan ke-4 dilakukan posttest dengan instrumen berupa soal essay.

Instrumen pengumpulan data yang digunakan yaitu lembar observasi siswa, dokumen berupa video dan gambar kegiatan pembelajaran, dan soal post-test. Observer yang bertugas mengobservasi aktivitas siswa adalah guru kimia. Soal post-test yang digunakan terdiri dari 8 soal essay tentang materi koloid dengan penskoran 3-0.

Analisis data menggunakan indeks Gregory untuk mengetahui validitas isi soal posttest, rumus product moment untuk mengetahui validitas butir soal dan rumus alpha untuk mengetahui reliabilitas instrumen serta statistik uji-t untuk menguji hipotesis penelitian. Pengujian normalitas dilakukan dengan rumus chi-kuadrat dan uji homogenitas menggunakan rumus uji-F.

\section{HASIL DAN PEMBAHASAN}

Hasil penelitian menunjukkan bahwa kemampuan berpikir kritis siswa yang diperoleh berupa data hasil belajar dalam ranah kognitif pada materi koloid. Post-test dilakukan pada kelas XI MIA 4 (kelas eksperimen) dengan jumlah siswa 38 orang dan kelas XI MIA 1 (kelas kontrol) yang berjumlah 37 orang siswa. Rangkuman data dan grafik hasil post-test siswa disajikan pada gambar 1 . 


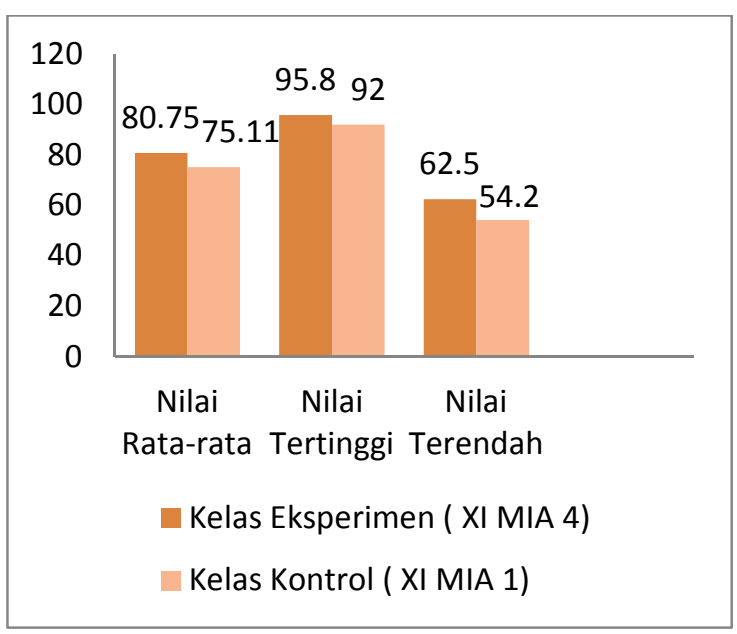

Gambar 1. Grafik Hasil Post-Test

Gambar di atas, menunjukan bahwa nilai rata-rata, nilai tertinggi dan nilai terendah kelas eksperimen lebih tinggi dibandingkan kelas kontrol.

Data hasil belajar siswa kemudian dianalisis dengan menggunakan uji ancova (analysis of covariance). Hasil uji hipotesis yang dilakukan diperoleh nilai fhitung sebesar 8,15 sementara untuk nilai ftabel pada taraf signifikan $5 \%$ diperoleh sebesar 3,98. Berdasarkan hasil perhitungan tersebut dapat diketahui bahwa nilai untuk fhitung $>$ ftabel yang menunjukkan bahwa Ho ditolak yang artinya penerapan model pembelajaran inkuiri terbimbing dengan metode pembelajaran terpadu pada materi koloid memberikan pengaruh terhadap kemampuan berpikir kritis siswa kelas XI MIA MAN 1 Lombok Timur.

Hasil observasi menunjukkan bahwa aktivitas belajar siswa kelas eksperimen lebih tinggi dibanding kelas kontrol.

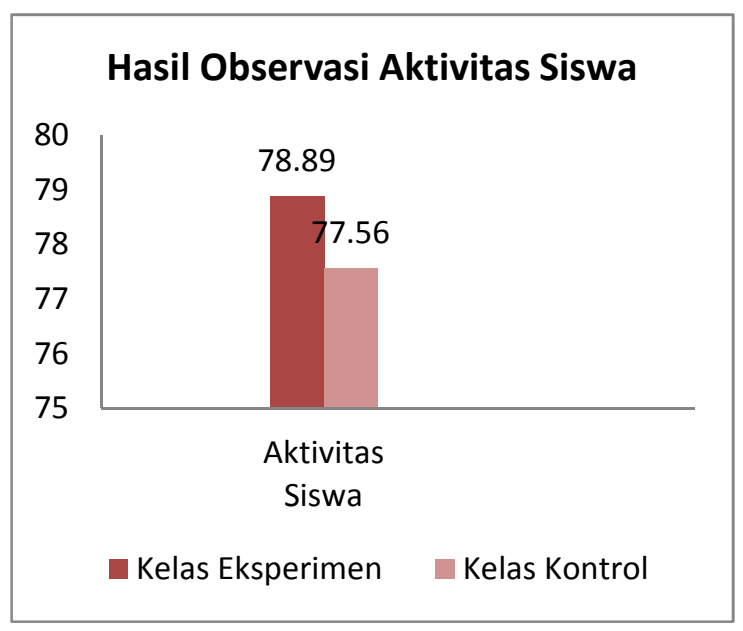

Gambar 2. Hasil Observasi Aktivitas Siswa
Pada proses pembelajaran ini, aktivitas yang dilakukan oleh siswa pada kelas eksperimen lebih tinggi dibanding kelas kontrol. Penyebabnya dikarenakan kelas eksperimen menerapkan model pembelajaran inkuiri terbimbing dengan metode pembelajaran terpadu dimana guru sebagai fasilitator dan siswa yang berperan aktif dalam proses pembelajaran. Keterlibatan siswa secara aktif dalam proses pembelajaran mempengaruhi keberhasilan dalam belajar karena apa yang dipelajari akan tertanam serta siswa mampu membangun pengetahuannya sendiri.

Peningkatan aktivitas belajar siswa dari tiap-tiap metode pada metode pembelajaran terpadu dikaitkan dengan indikator-indikator kemampuan berpikir kritis dapat mengindikasikan meningkatnya kemampuan berpikir kritis siswa. Adapun aktivitas belajar pada metode pictorial riddle yaitu siswa mengamati suatu gambar mengenai konsep yang akan dibahas, siswa merumuskan pertanyaan yang berhubungan dengan gambar, siswa mengemukakan argumen dan menyatukan argumen mereka terkait gambar yang telah ditampilkan (Awal et al, 2014). Aktivitasaktivitas tersebut berkaitan dengan indikator kemampuan berpikir kritis yaitu memfokuskan pertanyaan. Ennis (2011) mengemukakan bahwa kemampuan memfokuskan pertanyaan memengaruhi seseorang untuk dapat mengidentifikasi dan merumuskan pertanyaan serta kriteria-kriteria untuk mempertimbangkan jawaban yang mungkin. Aktivitas mengemukakan dan menentukan argumen berkaitan dengan indikator menganalisis argumen dan indikator bertanya dan menjawab pertanyaan. Menganalisis argumen berhubungan langsung dengan kemampuan menganalisis seseorang, seseorang yang mampu memberikan alasan yang tepat dalam menjawab sebuah pertanyaan dapat dipastikan ia pun memiliki kemampuan menganalisi yang tinggi.

Hidayati (2012) mengungkapkan aktivitas-aktivitas belajar siswa pada metode praktikum yaitu siswa mengamati suatu objek, keadaan atau proses, menganalisis dan mengumpulkan data mengenai suatu objek, keadaan atau suatu proses. Henny (2011) mengemukakan bahwa aktivitas mengamati, menganalisis dan mengumpulkan data mengenai suatu percobaan berkaitan dengan indikator membangun keterampilan dasar yaitu mempertimbangkan apakah sumber dapat 
dipercaya atau tidak, indikator mengobservasi dan mempertimbangkan laporan observasi, serta indikator membuat dan menentukan hasil pertimbangan. Nugraha \& Kirana (2015) menyatakan kredibilitas merupakan kemampuan untuk mengetahui keahlian dan reputasi sumber, menggunakan sumber yang baku, mampu memberikan alasan. Indikator mengobservasi dan mempertimbangkan laporan observasi merupakan kemampuan untuk melibatkan sedikit dugaan berdasarkan fakta yang diperoleh dan menggunakan bukti-bukti yang benar untuk dapat dilaporkan (Henny, 2011). Siswa dikatakan memiliki kemampuan membuat dan menentukan hasil pertimbangan dalam berpikir kritis jika mereka dapat mengemukakan sebuah pertimbangan yang diyakini dan mampu menentukan tindakan berdasarkan fakta-fakta yang telah dikumpulkan (Purwanto \& Winarti, 2016). Kemampuan mendefinisikan istilah dan mempertimbangkan suatu definisi dapat dilihat ketika siswa mampu mengemukakan arti atau makna istilah, simbol mamupun rumus yang mereka kerjakan untuk menjawab suatu permasalahan berdasarkan data-data yang telah diperoleh (Henny, 2011).

Usman (1992) mengungkapkan beberapa aktivitas belajar siswa pada metode diskusi kooperatif tipe STAD yaitu menemukan masalah yang layak didiskusikan, menjelaskan masalah, mengajukan pendapat, melakukan tanya jawab, mengarahkan situasi sesuai topik bahasan, mengemukakan solusi dari permasalahan, dan menyimpulkan. Siswa dikatakan memiliki kemampuan menyimpulkan dan mengidentifikasi asumsi-asumsi jika dalam menjawab pertanyaan siswa dapat memberikan jawaban dengan alasan yang tepat dari persoalan yang disampaikan baik secara umum maupun khusus (Ernest, 1991). Kemampuan mendefinisikan istilah dan mempertimbangkan suatu definisi dapat dilihat ketika siswa mampu mengemukakan arti atau makna istilah, simbol mamupun rumus yang mereka kerjakan untuk menjawab suatu permasalahan. Siswa dikatakan mampu menjaga situasi dalam berpikir kritis jika dalam menanggapi pertanyaan tidak melenceng jauh dari topik yang ditanyakan. Jadi mereka membicarakan hanya dalam ranah materi atau konsep yang berhubungan dengan pertanyaan saja. Aktivitas ini berkaitan dengan indikator menentukan suatu tindakan (Julie \& Dorothy, 2007).

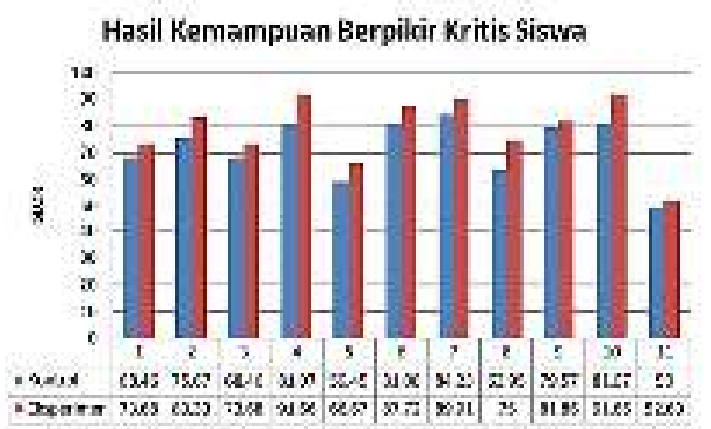

Gambar 3. Hasil kemampuan berpikir kritis siswa

Penelitian ini selanjutnya mengukur 11 indikator keterampilan berpikir kritis Robert $\mathrm{H}$. Ennis yang disajikan dalam grafik hasil posttest dari kontrol dan kelas eksperimen pada Gambar 3.

Gambar 3. Perbedaan Persentase Ratarata antara Kontrol dan Kelas Eksperimental berdasarkan Indikator Keterampilan Berpikir Kritis.

Indikator kemampuan berpikir kritis yang diukur sebanyak 11 indikator, yakni 1) memfokuskan pertanyaan, 2) menganalisis argumen, 3) bertanya dan menjawab pertanyaan, 4) mempertimbangkan apakah sumber dapat dipercaya atau tidak, 5) mengamati dan menilai laporan observasi, 6) membuat deduksi dan mempertimbangkan hasil deduksi, 7) menginduksi dan mempertimbangkan hasil induksi, 8) membuat dan menilai hasil pertimbangan, 9) mendefinisikan istilah dan mempertimbangkan definisi, 10) mengidentifikasi asumsi-asumsi, 11) memutuskan suatu tindakan. Perbedaan terlihat pada hasil posttest dari kelas kontrol dan kelas eksperimen. Berdasarkan grafik hasil kemampuan berpikir kritis menunjukkan bahwa penggunaan model inkuiri terbimbing dengan metode pembelajaran terpadu memiliki nilai yang tinggi secara dibandingkan dengan kelas kontrol yang menggunakan model pembelajaran konvensional dengan metode ceramah dan diskusi pada keseluruhan indikator kemampuan berpikir kritis. Kelas di mana model inkuiri terbimbing dengan metode pembelajaran terpadu diterapkan menerima tanggapan positif dari siswa dan berhasil meningkatkan berpikir kritis siswa (Astyana et al, 2017). Model inkuiri terbimbing dengan metode pembelajaran terpadu didahului dengan presentasi masalah. Model inkuiri terbimbing memulai kegiatan 
pembelajaran ketika siswa menerima dan mengidentifikasi masalah (Ngalimun, 2016). Berdasarkan uraian indikator keterampilan berpikir kritis dari kelas kontrol dan kelas eksperimen, dapat disimpulkan bahwa kelas eksperimen memperoleh rata-rata yang lebih tinggi daripada kelas kontrol. Ini dapat dimengerti karena tahapan model pembelajaran inkuiri terbimbing dengan metode pembelajaran terpadu mampu menciptakan suasana aktif yang melibatkan proses berpikir untuk mendukung keterampilan berpikir kritis siswa. Siswa di kelas eksperimen dilatih untuk terbiasa dengan masalah / masalah kontekstual dalam kehidupan sehari-hari. Pemecahan masalah dilakukan melalui pengambilan informasi independen oleh siswa dan mencari solusi yang tepat untuk memecahkan masalah. Ini dapat meningkatkan keterampilan berpikir kritis siswa dan memungkinkan mereka untuk menjadi pemikir aktif dalam kegiatan belajar.

\section{KESIMPULAN}

Berdasarkan hasil penelitian dan pembahasan, dapat disimpulkan bahwa penerapan model pembelajaran inkuiri terbimbing dengan metode pembelajaran terpadu memberikan pengaruh yang lebih baik terhadap kemampuan berpikir kritis.

\section{SARAN}

Berdasarkan penelitian yang telah dilakukan, peneliti mengajukan saran untuk keberlanjutan penelitian ini yaitu:

1. Guru hendaknya mengembangkan wawasan dan memahami masalah yang dihadirkan dengan baik agar dapat memfasilitasi siswa dalam mengembangkan keterampilan berpikir kritisnya selama proses pembelajaran.

2. Guru yang ingin menerapkan model pembelajaran inkuiri terbimbing dengan metode pembelajaran terpadu, sebaiknya dapat mengatur waktu agar seluruh tahapan model pembelajaran inkuiri terbimbing dengan metode pembelajaran terpadu dapat terlaksana dengan maksimal.

3. Diharapkan adanya penelitian lebih lanjut mengenai model pembelajaran lain yang dapat meningkatkan keterampilan berpikir kritis siswa.

\section{DAFTAR PUSTAKA}

Aftriani, D.N., Muntari, Haris, M., \& Anwar, Y.A.S. (2019). Pengaruh Pembelajaran Inkuiri Terbimbing Pada Pelajaran Kimia Terhadap Kemampuan Berpikir Kreatif Siswa Kelas XI IPA SMAN 2 Mataram. Chemistry Education Practice, 1(2), 1-6.

Astyana, K., Leny \& Saadi, P. (2017). Pengaruh Model Inkuiri Terbimbing Bervisi SETS terhadap Keterampilan Proses Sains dan Hasil Belajar Larutan Penyangga Siswa Kelas XI PMIA SMAN 3 Banjarmasin. JCAE, Journal of Chemistry And Education, 1(1), 65- 72.

Awal, S., Ahmad, Y., Bunga, D. A. (2014). Peranan Metode Pictorial Riddle Terhadap Penguasaan Konsep Fisika Pada Siswa SMAN 1 Bontonompo. Jurnal Pendidikan Fisika, 4(2), 249-265.

Ennis, R.H. (2011). The Nature of Critical Thinking: An Outline of Critical Thinking Dispositions and Abilities. USA: University of Illinois.

Ernest, P. 1991. The Philosophy of Mathematics Education. New York: The Falmer Press.

Henny, I. (2011). Meningkatkan Keterampilan Berpikir Kritis Mahasiswa Melalui Implementasi Model Controversial Issues Pada Mata Kuliah Ekonomi Sumber Daya Manusia dan Alam. Jurnal Pendidikan Ekonomi dan Bisnis, 4(1), 63-70.

Hidayati, N. (2012). Penerapan Metode Praktikum dalam Pembelajaran Kimia untuk Meningkatkan Keterampilan Berpikir Tingkat Tinggi Siswa pada Materi Pokok Kesetimbangan Kimia Kelas XI SMK Diponegoro Banyuputih Batang. Skripsi. Semarang. IAIN Walisongo.

Julie, C. \& Dorothy, H. (2007). An Evaluation of a School Programme for The Development of Thinking Skills Through 
The Case. International Journal of Science Education, 30(2), 185-202.

Ngalimun. (2013). Strategi dan Model Pembelajaran. Yogyakarta : Aswaja Pressindo.

Purwanto, J. \& Winarti. (2016). Profil Pembelajaran Fisika dan Kemampuan Berpikir Kritis Siswa Madrasah Aliyah se-DIY. Jurnal Penelitian Pembelajaran Fisika, 7(2), 8-18.

Rahmadani, P. \& Dian, N. (2018). Keterampilan Berpikir Kritis Siswa Pada Materi Laju Reaksi di Kelas XI MIA SMA Nergeri 1 Manyar. Jurnal Pembelajaran Kimia, 3(2): 19-30.

Resti, S. N. E. (2014). Hubungan Motivasi Berprestasi Siswa dan Kemampuan Berpikir Kritis Siswa Dengan Hasil Belajar Ilmu Pengetahuan Sosial (IPS) Siswa. Tesis. Jakarta: Universitas Negeri Jakarta.

Sugiyono. (2014). Statistika untuk Penelitian. Bandung: Alfabeta.

Surachman, Y. (2010). Hubungan Pemahaman Konsep dan Kemampuan Berpikir Kritis dalam Pembelajaran Berbasis Proyek Mata Pelajaran Biologi Kelas X di Malang. Skripsi. Malang: Universitas Negeri Malang.

Usdalifat, Sri., Achmad, R., Samsurizal, M. S. (2016). Pengaruh Model Pembelajaran Inkuiri Terhadap Kemampuan Berpikir Kritis dan Keterampilan Proses Siswa Pada Mata Pelajaran IPA Biologi Kelas VII SMP Negeri 19 Palu. Jurnal Sains dan Teknologi Taduloko, 5(3), 1-10. 